\title{
THE PROFILE OF BAMA BEACH BASED ON THE SUBSTRATE, THE PRESENCE OF SEAGRASS, CORAL LIFEFORM, AND ECHINODERMATA
}

\author{
Noorafebrianie Minarputri1, 2, Noer Moehammadi1, Bambang Irawan'1 \\ 1Department of Biology, Faculty of Science and Technology Airlangga University \\ 2nooradrajat@gmail.com
}

\begin{abstract}
Bama Beach is one of the most visited beaches in Baluran National Park, Situbondo. However, this beach does not have information of beach profile which is very important for managing coastal and marine resources. The aims of this research are to make beach profiles based on substrate, presence of seagrass, coral lifeforms, and Echinodermata. This research's method is qualdrate transect. Five transects were made, roll meter pulled from the highest tides zone to the reef crest. The distance between each transect around 35-40 m. Plots $1 \times 1 \mathrm{~m}^{2}$ were placed along each transect with 8-15 m gap between each plot. Geographical coordinates were noted for each plot so the results are data in those plots. The results are the dominant substrate in Bama Beach is sand and always mixed with gravel. Boulders specifically found in the highest tides zone and close to the reef crest. Seagrass can be found almost in all plots, about 10 to $250 \mathrm{~m}$ from the highest tides zone. The dominant coral lifeform on reef flat is coral submassive; then approaching the reef crest, the coral massive is the dominant one. At Bama Beach, was found 5 classes and 9 orders of Echinodermata. Asteroidea with order Valvatida and Spinulosida; Ophiuroidea with order Ophiurida; Echinoidea with order Camarodonta, Diadematoida, Stomopneustoida; Holothuroidea with oder Aspidochirotida and Apodida; and Crinoidea with order Comatulida. Those orders live in all zones, which are sandy zone, seagrass zone, and coral reef zone.
\end{abstract}

Keywords: Bama beach profile, substrate, seagrass, coral lifeform, Echinodermata

\section{INTRODUCTION}

Bama beach, located in Baluran National Park Situbondo, is one of the most visited beaches in Baluran, not only by tourists but also by researchers, because it's easily accessed. The researchers come to Bama because the beach has 3 coastal ecosystems which are mangrove, seagrass, and coral reef ecosystem. With those different ecosystems, substrate composition in Bama beach varies from coastal line to reef crest. Substrate is the place where animals or plants attach or crawl (Riniatsih and Kushartono, 2009). Substrate type determines which living things live there.

Seagrass ecosystem in Bama beach is located between mangrove and coral reef ecosystem. Nybakken (1993) said, seagrass can live in all substrate type, however dense seagrass meadow can be found in soft bottom substrate. Seagrass ecosystem has important role in ecology. It can reduce turbidity so clear up the surrounding water. This ecosystem is also a habitat and nursery ground for economically important animals, such as shrimps and oysters.

Coral reef composed by coral animals and zooxanthellae, microcellular algae live in the coral tissue (English et al.,
1994). Coral larvae, called planula, have to attach on the substrate to be able to transform into coral colony (Harrison and Wallace, 1990). Richmond (1997) explained that substrate type is one of the most important factors in planula's attachment. Coral colony then identified based on its lifeform. Sumadhidarga and Moosa (1997) described the role of coral reef ecosystem, for instance it protects the beach from storm, wave, and prevents from abrasion. This ecosystem is spawning, nursery, and protection area for many sea creatures.

Echinodermata is a phylum that covers 5 classes and 36 orders, including seastars, sea urchins, and sea cucumbers (Ruppert et al., 2004). These animals are the most conspicuous animals in the seagrass beds (Yusron, 2009) and coral reef (Nybakken, 1993). One of the factors influence the local dispersion of this fauna is the substrate type (Aziz and Al-Hakim, 2007).

Unfortunately, Bama beach does not have information about its beach profile whereas the beach has many coastal potential, both for research and tourism purpose. Therefore, this work is aimed to make beach profiles based on the substrate, the presence of seagrass, coral lifeforms, and the presence of Echinodermata. 


\section{METHOD}

The field observation and data collection were conducted in August 28 ${ }^{\text {th }}-$ Sept $1^{\text {st }}$ and October $20^{\text {th }}-21^{\text {st }} 2012$ at Bama beach. Five transects were made, roll meter pulled from the highest tides zone to the reef crest. The distance between each transect around $35-40 \mathrm{~m}$. Plots $1 \times 1 \mathrm{~m}^{2}$ were placed along each transect with 8-15 m gap between each plot. Geographical coordinates were noted for each plot so the results are data at those plots. Salinity, water $\mathrm{pH}$, and temperature were measured to know the water condition. Salinity and $\mathrm{pH}$ were measured at each transect, whereas temperature was measured in each plot.

In this research, substrate was classified into 4 groups which are rock, gravel, sand, and mud. Coral lifeform identification based on English et al. (1994). Echinodermata identification based on Clark and Rowe (1971), Allen and Steene (1994), Colin and Arneson (1995), Gosliner et al. (1996), Jeng (1998), Susetiono (2004), and Yasin et al. (2008).

\section{RESULT}

Bama beach has 3 coastal ecosystems which are mangrove, seagrass, and coral reef ecosystem. There are

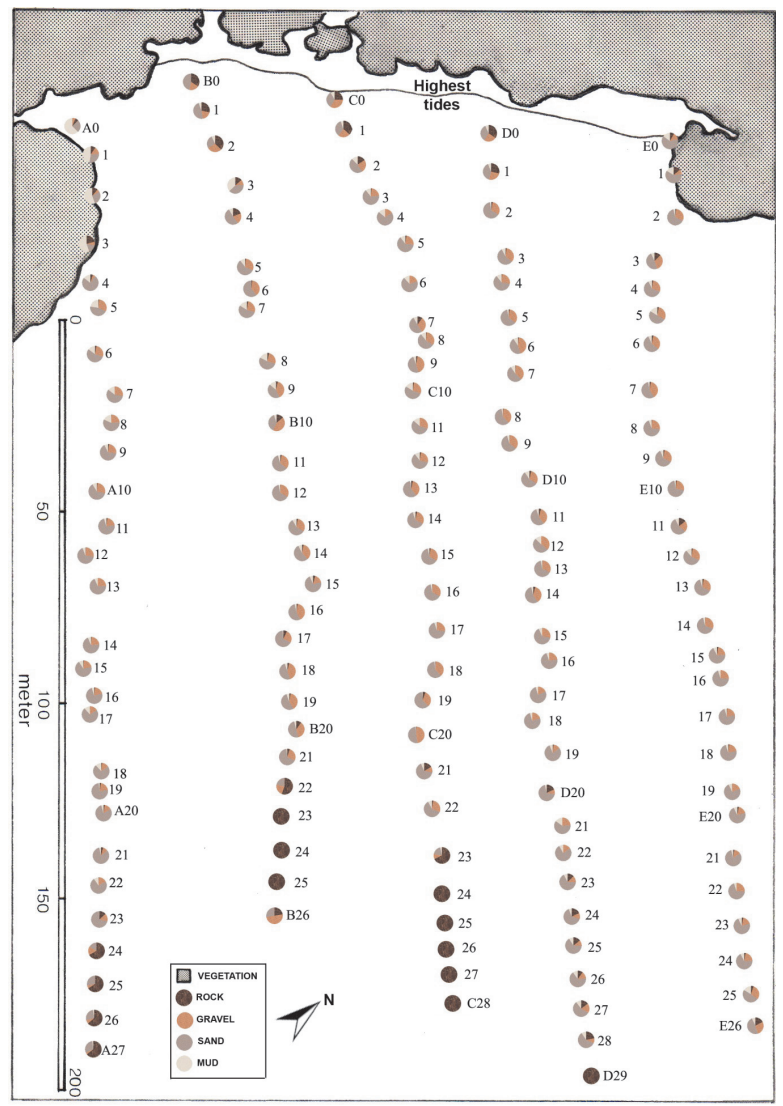

Figure 1. The profile of Bama beach based on substrate type in August - October 2012
2 mangrove communities, at south east and north east sides and bordered the beach. This white sand beach has approximately $162 \mathrm{~m}$ coast line and broad intertidal zone. When the spring tide occurs, seagrass and most of the reef flat exposed to the air. Bama beach is also known for its light wave. Salinity in Bama beach ranging from 34 to $35 \%$ while $\mathrm{pH}$ value around 7 and 8 . Water temperature ranged from 25 to $30^{\circ} \mathrm{C}$.

In this work, each plot has a varied composition of the substrate (Figure 1). Some plots, which are A0 to A6 and E0 to E5, have a high percentage of mud, ranged from 15 to $63 \%$. Other plots which are near the highest tide (B0 to $\mathrm{B} 4, \mathrm{C} 0$ to $\mathrm{C} 2$, and $\mathrm{D} 0$ to $\mathrm{D} 1$ ) have a high percentage of rock, range from 16 to $37 \%$. The dominant substrate in the last plots on each transect is rock, in form of rubbles with algae. Most plots, almost $70 \%$ of the sampling plots, dominated by sand and always mixed with gravel.

As Figure 2 shows, most of the plots covered by seagrass, approximately 10 to $250 \mathrm{~m}$ from the highest tide. Thalassia hemprichii and Enhalus acoroides are 2 species among others found in the beach. However, at some plots (A0 to A2, B0 to B1, C0, D0, and E0) seagrass is absent. Seagrass also absent in plots at the rubble rampart zone.

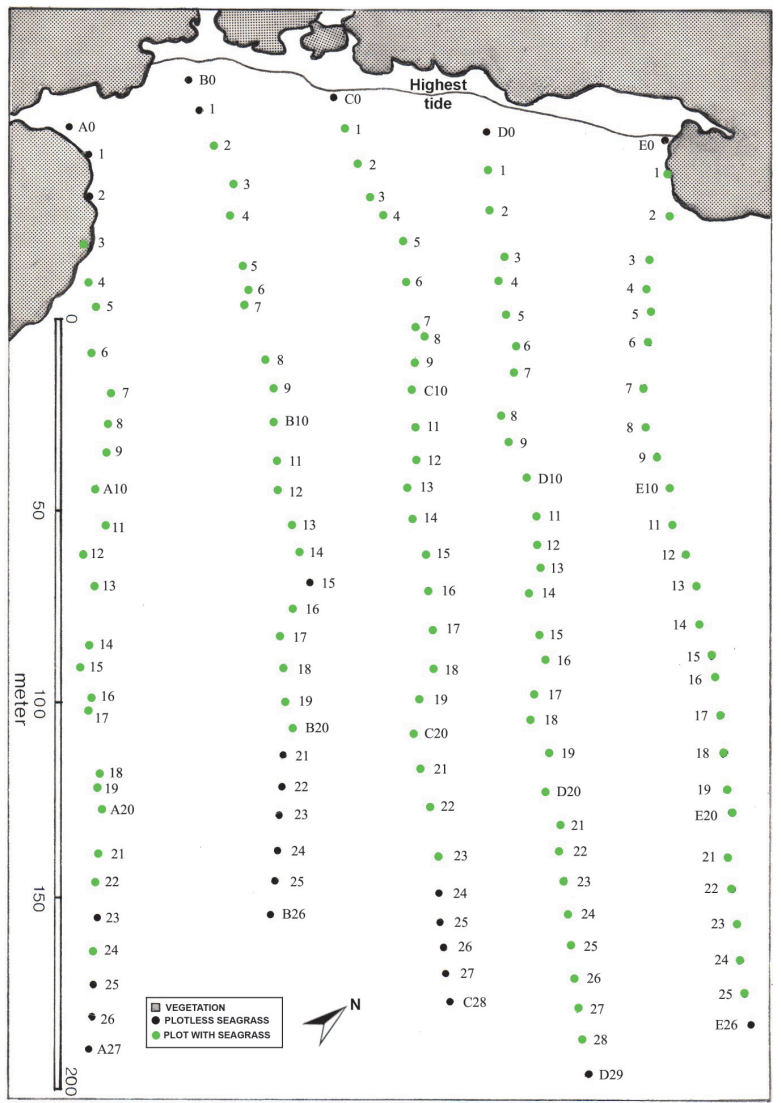

Figure 2. The profile of Bama beach based on the presence of seagrass in August - October 2012 


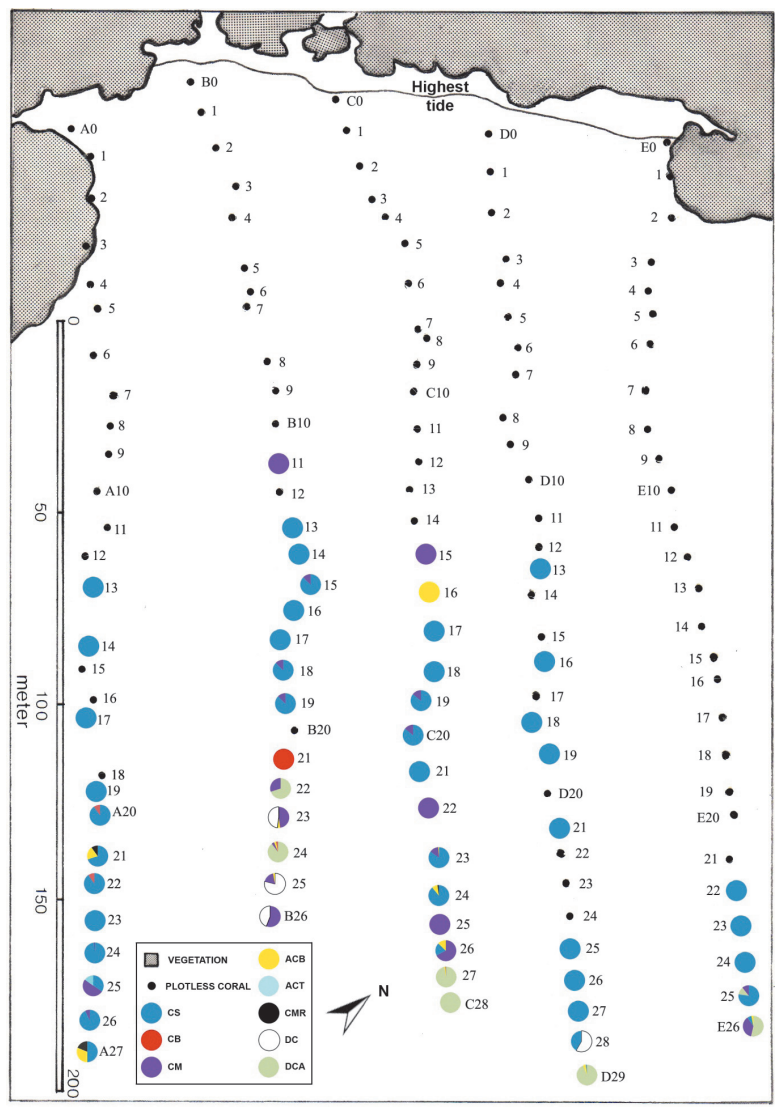

Figure 3. The profile of Bama beach based on the presence of coral lifeform in August October 2012

Coral reef colony was found at some plots (Figure 3). Eight lifeforms were found at Bama beach are coral submassive (CS), coral branching (CB), coral massive (CM), coral mushroom (CMR), Acropora branching (ACB), Acropora tabulate (ACT), dead coral (DC), and dead coral with alga (DCA). Reef flat dominated by CS. Reef flat zone composed of a high variation of coral lifeforms, such as $\mathrm{ACB}, \mathrm{CB}, \mathrm{CMR}$, and ACT. As Figure 3 shows branching lifeform (ACB and $\mathrm{CB}$ ) can be found in more plots than tabulate (ACT).

All five classes of Echinodermata can be found in Bama beach (Figure 4). The first class is Asteroidea. Two orders of the Asteroidea i.g. Valvatida and Spinulosida never be found under rock, but some individuals burry themselves in sand. The second class is the Ophiuroidea. The individuals of this class hide themselves by burying in substrate or under the coral submassive and coral massive. All of these individuals are the member of order Ophiurida, no members of the other order were found. The next class is Echinoidea which is represented by 3 orders, i.g. Camarodonta, Diadematoida, and Stomopneustoida. Most of these individuals were found in the crevices, but some are covered with seagrass

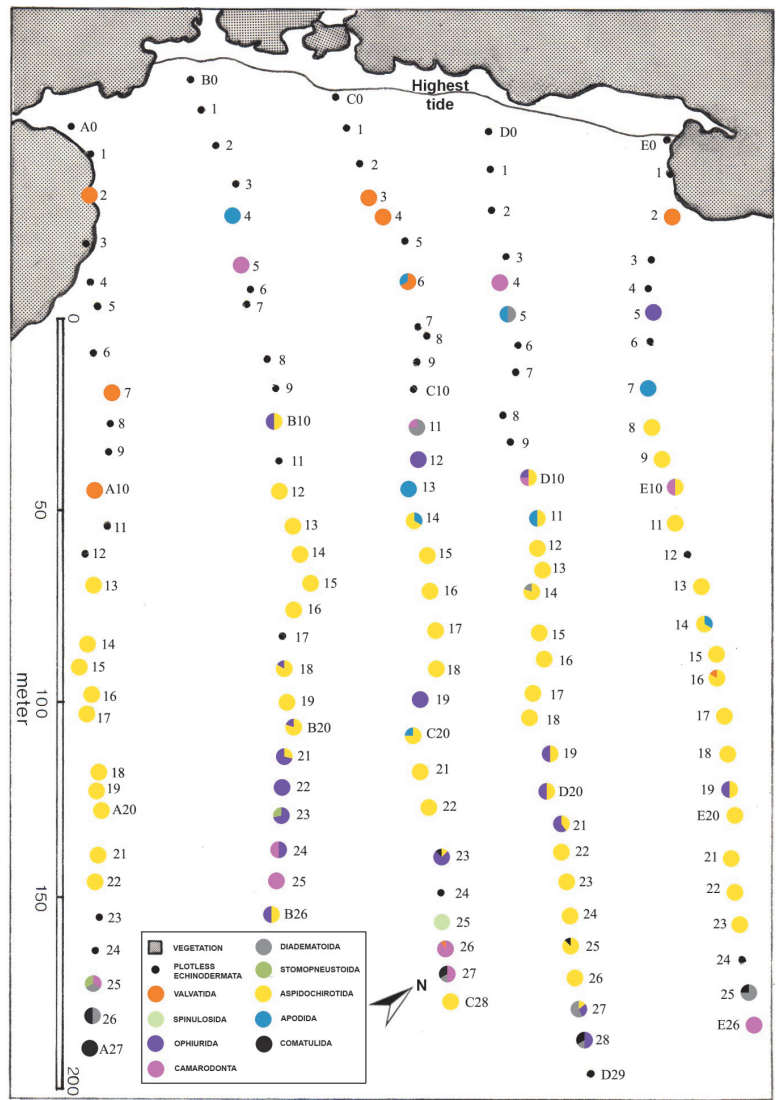

Figure 4. The profile of Bama beach based on the presence Echinodermata in August-October 2012

leaves. Holothuroidea is the fourth class can be found. This class is represented by 2 orders i.g. Aspidochirotida and Apodida. Most of these animals were found in seagrass bed. Comatulida of the Crinoidea was found in coral reef at Bama beach.

\section{DISCUSSION}

The salinity at Bama beach ranged from 34 to $35 \%$, this is still in the tolerance range for sea creatures. Threshold value for sea biota is $\pm 10 \%$ from normal salinity (Anonim, 1988). According to Romimohtarto and Thayib (1982) as cited by Yusron and Edward (2000), salinity in a beach ranged from 32 to $34 \%$, therefore the threshold is 29 to $37 \%$.

Effendi (2003) argues most of the sea creatures can live in $\mathrm{pH}$ value ranging from 7 to 8.5 which means $\mathrm{pH}$ value at Bama beach is in good condition for living sea creatures. The substrate composition also influences the $\mathrm{pH}$ level. Feryatun et al. (2012) stated that substrate composed from rubbles, shells, and sand causes the water more alkaline. This is because rubbles and shells were made from calcium carbonate, which is alkaline, so it affects the $\mathrm{pH}$ value. 
The wide range of temperature at Bama beach caused by the different time the data collection, in the noon at some plots and in the afternoon at others. Lüning dan Asmus (1991) stated that normal temperature at sea surface of the tropic area is 26 to $30^{\circ} \mathrm{C}$. Threshold range for temperature must at normal range (Anonim, 1988). Although the temperature range in Bama beach quite wide, this value is still on the temperature range for sea creatures to live.

Substrate is one of the most important abiotic factors that affects existence of a creature. Mud is perfect for mangrove growth. According to Dahuri (2003), mangrove grows optimally in coastal area with a big river mouth which provides mud for its growth. Therefore, at that area mangrove can be found. The plots near the highest tide have rubbles that are collected by wave every day. Nybakken (1993) said there are swash and backwash in the beach. Swash is the turbulent flow of water that washed up on the beach after incoming wave has broken, while backwash is the flow back to the ocean. Swash often brought particles from the ocean to the beach, whereas the backwash brought back some particles based on its size. Because rubbles quite big in size, swash can brought them to the beach, but backwash can't brought them back to the ocean, that is why the rubbles can be found near the highest tide.

The dominant substrate at last plots on each transect is rock. According to Aziz (1996), reef crest zone consist of rubble rampart and Acropora rampart. That zone composed from rubbles and dead boulders. Thus, those last plotson each transect (A24 to A27, B22 to B26, C23 to C28, D29, and E26) belonging to the rubble rampart zone. Rampart zone composed from rubbles because the wave strokes the crumbly branching coral (Lerman, 1986).

Sand in the beach is a result of beach erosion and also transformed rocks into sand on the way from rivers to the ocean (Meadows and Campbell, 1988). The dominant substrate at Bama beach is sand because of the wave action at the beach. Wave plays role in substrate motion. Lighter particles appear only in light wave motion beach; on the other hand, bigger size particles appear in heavy wave motion beach. In heavy wave motion beach, the lighter particles swept away to the open ocean while the bigger one precipitate (Nybakken, 1993). By its light wave motion, dominant substrate in Bama beach is sand. However, that wave motion is strong enough to sweep away the lighter particle, which is the mud, thus Bama beach is not a muddy beach.

Seagrass can grow in all of the substrate types (Dahuri, 2003). The substrate composition at Bama beach is perfect for seagrass to grow. It shows in Figure 2, most of the plots were covered by seagrass. Seagrass can grow optimally in light wave motion. As El Shaffai (2011) said, abundance and distribution of seagrass are also affected by the wave motion. Because Bama beach has light wave motion, seagrass are found in most plots. However, in some plots (A0 to A2, B0 to B1, C0, D0, and E0) seagrass is absent. This is caused by the infrequent submerge time of these plots which are submerged only when the highest tide comes. Seagrass also absent in plots at the rubble rampart zone because of the unstable substrate on that zone.

As shown in Figure 3, the dominant coral lifeform is CS. Worachananant et al. (2006) explained that CS is the most tolerant lifeform. It resistant to disturbances including covered by sand, being up-turned, and breakage. At Bama beach, CS mostly lives on sand substratum, while other lifeforms live on rubbles. According to Richmond (1997), substrate type is one of the most important factors in planula's attachment. Planula prefers the solid substrate. Rubbles are more stable to wave disturbance than sand (Pitasari et al., 2011). For that reason, rubbles-dominant plots have higher lifeform variation than sand-dominant plots.

Eventhough sand is an unstable substrate, at Bama beach, coral colony can be found in sand-dominated plots. That is because, in those plots seagrass grow and help stabilizing the sea bottom. Nybakken (1993) said, seagrass's root weaving in substrate so it can stabilize the sea floor. Plots near the highest tide, the dominant substrate are sand. At those plots also grow seagrass but coral colony is absent in those plots. That is because those plots exposed to the air longer that plots in reef flat. Coral colony can't live if it is exposed to the air too long.

The branching lifeform (ACB and $\mathrm{CB}$ ) can be found in more plots than tabulate (ACT). Falkowski et al. (1990) described that shallow water coral community tends to form branching, while the deeper community forms tabulate and encrusting lifeform. That different lifeform is an adaptation in order to get as much sunlight as possible. Approaching to the reef crest zone, CM can be easily found. That is because CM more resistant to direct impact from the wave (Lerman, 1986 and Worachananant et al., 2006).

All five classes of Echinodermata can be found in Bama beach (Figure 4). The first class is Asteroidea. Two orders of the Asteroidea i.g. Valvatida and Spinulosida have their own distinction. Valvatida characterized by their conspicuous marginal plates (Anonim, 2012). Those plates armed with spines to protect themselves (Mah and Blake, 2012). Members of this order can be found in many habitat, such as rocky beach, sandy beach, and seagrass bed 
(Anonim, 2012). Spinulosida have relatively small central disc and cylindrical arms. This order have little amount of pedicellariae (Anonim, 2012). Members of this order also can be found in vary habitat, from rocky to sandy beach and in seagrass meadow (Reeds, 2002).

Second class found at Bama beach is Ophiuroidea, also known as brittle star. In Bama beach individuals of the class hide themselves by burying in substrate or under the coral submassive and coral massive. As Aziz (1996) and Stöhr et al. (2012) said, Ophiuroidea have adapted to a wide variety of life-styles. Most species are bottom dwellers, buried themselves in mud or sand, also hide in crevices in rock or coral. Individuals were found are the member of order Ophiurida. Ruppert et al. (2004) declared that Ophiurida have thin epidermis and horizontally-move arms. This order comprises most species in the class Ophiuroidea.

The next class is Echinoidea, which is represented by 3 orders i.g. Camarodonta, Diadematoida, Stomopneustoida. Camarodonta likely found in intertidal zone (McRae, 1958) and most living species of Echinoidea comprised in this order (Kroh and Smith, 2010). Members of Camarodonta at Bama beach were found in seagrass beds and in crevices of coral massive. Diadematoida distinguish by its needlelike and hollow spines (Anonim, 2012). At Bama beach, this order was found in seagrass beds and coral reef. Stomopneustoida is the third order was found at Bama beach. Kroh (2012) said, this order lives in crevices and bore rocks. This animal can be found in intertidal zone all over the world.

Holothuroidea, known as sea cucumber, is represented by Aspidochirotida and Apodida. Aspidochirotida mainly distributed in shallow water of the tropics. Their elongated bodies with 15-30 peltate tentacles are different from the others. Species in this order can be found in any substrate type, e.g. mud, gravel, and rubbles (Aziz, 1995). At Bama beach, this order was found in most of the plots (Figure 4). Apodida differ from other orders because their wormlike bodies and no tube feet developed (Ruppert et al., 2004). At Bama beach, Apodida can be found in seagrass bed, specifically in seagrass species $T$. hemprichii and $E$. acoroides, which have long leaves. That leaves help them camouflage themselves.

Crinoidea is a class of Echinodermata that looks like a plant. Some species of this class adapted to attach at mud, however the most suitable habitat for Crinoidea is coral reef. Because of that, Crinoidea was found in coral reef at Bama beach. Comatulida is the only order of this class can be found at Bama beach. This order mainly lives in shallow water and love solid substrate with strong wave motion (Aziz et al., 1991). As Figure 4 shows, Comatulida was found in plots near the reef crest zone. That is because Crinoidea also avoids estuary and river mouth which change the salinity (Aziz, 1994). Crinoidea depends on plankton population which is why this class more often found in outer zone of the coral reef (Aziz, 1996).

Based on the discussion above, the profile of Bama beach based on the substrate type is dominanted by sand. Rocks are found in plots near the highest tide and the coral rampart zone. Seagrass can be found in most of the plots, approximately 10 to $250 \mathrm{~m}$ from the highest tide. Reef flat zone composed with a high variation of coral lifeforms. The dominant lifeform is coral submassive. Approaching to the reef crest, the coral massive is the dominant one. There are 5 classes and 9 orders found at Bama beach. Asteroidea with order Valvatida and Spinulosida; Ophiuroidea with order Ophiurida; Echinoidea with order Camarodonta, Diadematoida, Stomopneustoida; Holothuroidea with oder Aspidochirotida and Apodida; and Crinoidea with order Comatulida.

\section{REFERENCES}

Allen, G.R., dan Steene, R. 1994. Indo-Pacific Coral Reef Field Guide. Singapore: Tropical Reef Research.

Anonim, 1988. Keputusan Menteri Negara Kependudukan dan Lingkungan Hidup tentang Pedoman Penetapan Baku Mutu Lingkungan. Jakarta: Kementerian Negara Kependudukan dan Lingkungan Hidup.

Anonim, 2012. Echinodermata. www.rmbr.nus.edu.sg: 14 Desember 2012.

Aziz, A. 1994. Pengaruh Salinitas terhadap Sebaran Fauna Ekhinodermata. Oseana, 19(2): 23-32.

Aziz, A. 1995. Beberapa Catatan tentang Teripang Bangsa Aspidochirotida. Oseana, 20(4): 11-23.

Aziz, A. 1996. Habitat dan Zonasi fauna Ekhinodermata di Ekosistem Terumbu Karang. Oseana, 21(2): 33-43.

Aziz, A., and Al-Hakim, I. 2007. Fauna Ekhinodermata Perairan Terumbu Karang Sekitar Bakauheni. Oseanologi dan Limnologi di Indonesia, 33: 187-198.

Aziz, A., Sugiarto, H., and Supardi, 1991. Beberapa Catatan Mengenai Kehidupan Lili Laut. Oseana, 16(3): 17-24.

Clark, A.M., and Rowe, F.W.E. 1971. Monograph of ShallowWater Indo West Pacific Echinoderms. London: Trustees of the British Museum (Natural History).

Colin, P.L., and Arneson, C. 1995. Tropical Pacific Invertebrates: A Field Guide to the Marine Invertebrates Occuring on Tropical Pacific Coral Reefs, Sea grass Beds, and Mangroves. California: Coral Reef Press.

Dahuri, R. 2003. Kenakeragaman Hayati Laut: Aset Pembangunan Berkelanjutan Indonesia. Jakarta: PT. Gramedia Pustaka Utama. 
Effendi, H. 2003. Telaah Kualitas Air bagi Pengelolaan Sumber Daya dan Lingkungan Perairan. Yogyakarta: Kanisius.

E1 Shaffai, A. 2011. Field Guide to Seagrasses of the Red Sea. Rouphael, A. dan Abdulla, A., (eds.) $1^{\text {st }}$ ed. Gland, Switzerland: IUCN and Courbevoie, France: Total Foundation.

English, S., Wilkinson, C., and Baker, V. 1994. Survey Manual for Tropical Marine Resources. Townsville: Australian Institute of Marine Science.

Falkowski, P.G., Jokiel, P.L., and Kinzie III, R.A. 1990. Irradiance and Corals. In Dubinsky, Z. (ed.), Ecosystems of The World 25: Coral Reefs. New York: Elsevier Science Publishing Company Inc.

Feryatun, F., Hendrarto, B., and Widyorini, N. 2012. Kerapatan dan Distribusi Lamun (Seagrass) Berdasarkan Zona Kegiatan yang Berbeda di Perairan Pulau Pramuka, Kepulauan Seribu. Journal of Management of Aquatic Resources: 1-7.

Gosliner, T.M., Behrens, D.W., and Williams, G.C. 1996. Coral Reef Animals of the Indo-Pacific. California: Sea Challengers.

Harrison, P.L. and Wallace, C.C. 1990. Reproductive, Dispersal, and Recruitment of Scleractinian Corals. In Dubinsky, Z. (ed.), Ecosystems of The World 25: Coral Reefs. New York: Elsevier Science Publishing Company Inc.

Jeng, M. 1998. Shallow-water Echinoderms of Taiping Island in the South China Sea. Zoological Studies, 37(2): 137-153.

Kroh, A. 2012. Stomopneustes variolaris (Lamarck, 1816). In: Kroh, A., \& Mooi, R., (2012) World Echinoidea Database. Accessed through: World Register of Marine Species. www. marinespecies.org: 14 Desember 2012.

Kroh, A., and Smith, A.B. 2010. The Phylogeny and Classification of Post-Palaeozoic Echinoids. Journal of Systematic Palaeontology, 8(2): 147-212.

Lerman, M. 1986. Marine Biology: Environment, Diversity, and Ecology. California: The Benjamin/Cummings Publishing Company.

Lüning, K., and Asmus, R. 1991. Physical Characteristics of Littoral Ecosystems, with Special References to Marine Plants. In Mathieson, A.C. dan Nienhuis, P.H. (eds.), Ecosystem of the World 24: Intertidal dan Littoral Ecosystems. New York: Elsevier Science Publishing Company Inc.

Mah, C.L., and Blake, D.B. 2012. Global Diversity and Phylogeny of the Asteroidea (Echinodermata). PLoS ONE, 7(4): 1-22.

McRae, A. 1958. Evechinus chloroticus (Val.), and endemic New Zealand Echinoid. Transactions of the Royal Society of New Zealand, 86(3): 205-267.

Meadows, P.S., and Campbell, J.I. 1988. An Introduction to Marine Science $2^{\text {nd }}$ ed. New York: Halsted Press.

Nybakken, J.W. 1993. Marine Biology: An Ecological Approach $3^{\text {rd }}$ ed. New York: HarperCollins College Publishers.
Pitasari, A., Saptarini, D., and Aunurohim, 2011. Tingkat Rekrutmen Karang pada Tiga Tipe Substrat di Pantai Pasir Putih Situbondo. Skripsi. Surabaya: Institut Teknologi Sepuluh Nopember.

Reeds, K. 2002. Echinaster (Echinaster) sepositus. Red starfish. Marine Life Information Network: Biology and Sensitivity Key Information Sub-programme [on-line]. Plymouth: Marine Biological Association of the United Kingdom. [cited 13/12/2012]. Available from: http://www.marlin. ac.uk/speciesinformation.php? speciesID $=3225$

Richmond, R.H. 1997. Reproduction and recruitment in corals: Critical links in the persistence of reefs. In Birkeland, C (ed). Life and Death of Coral Reefs. New York: Chapman $\&$ Hall.

Riniatsih, I., and Kushartono, E.W. 2009. Substrat Dasar dan Parameter Oseanografi sebagai Penentu Keberadaan Gastropoda dan Bivalvia di Pantai Sluke Kabupaten Rembang. Ilmu Kelautan, 14(1): 50-59.

Ruppert, E.E., Fox, R.S., and Barnes, R.D. 2004. Invertebrate Zoology $7^{\text {th }}$ ed. California: Brooks/Cole.

Stöhr, S., O'Hara, T.D., and Thuy, B. 2012. Global Diversity of Brittle Stars (Echinodermata: Ophiuroidea). PLOS ONE, 7(3): 1-14.

Sumadhidarga, K., and Moosa, M.K. 1997. Program rehabilitasi dan Pengelolaan Terumbu Karang: Sebuah Upaya Penyelamatan Lingkungan Pesisir Indonesia. Prosiding Seminar. Jakarta.

Susetiono, 2004. Fauna Padang Lamun Tanjung Merah Selat Lembeh. Jakarta: Pusat Penelitian Oseanografi-LIPI.

Worachananant, S., Carter, B. and Hockings, M. 2006. Recovery and Management in Surin Marine National Park, Thailand. Disampaikan dalam Post-Disaster Assessment and Monitoring of Changes in the Coastal, Ocean and Human Systems in the Indian Ocean and Asian Waters, Phuket, Thailand. 20-23 Februari 2006.

Yasin, Z., Kwang, S.Y., Shau-Hwai, A.T., and Shirayama, Y. 2008. Field Guide to the Echinoderms (Sea Cucumbers and Sea Stars) of Malaysia. Kyoto: Kyoto University Press.

Yusron, E. 2009. Keanekaragaman Jenis Ekhinodermata di Perairan Teluk Kuta, Nusa Tenggara Barat. Makara Sains, 13(1): 45-49.

Yusron, E., and Edward, 2000. Kondisi Perairan dan Keanekaragaman Hayati di Perairan Teluk Tomini Sulawesi Utara. Disampaikan pada Seminar Nasional Pendayagunaan Sumberdaya Hayati dalam Pengelolaan Lingkungan Fakultas Biologi Universitas Kristen Satya Wacana Salatiga. 3 Juni 2000.

Note: this report is a part of a bachelor thesis of the first author under the supervision of the second and third author. 